\title{
Commercial formulations of Bacillus spp. for sugarcane pineapple disease control and growth promotion
}

\author{
Fabio Brandi(1), Daniel Winter Heck ${ }^{(1)}$, Thiago Costa Ferreira(1) and Wagner Bettiol(2)
}

(1)Universidade Estadual Paulista, Faculdade de Ciências Agrárias, Avenida Universitária, oㅡ 3.780, Altos do Paraíso, CEP 18610-034 Botucatu, SP, Brazil. E-mail: fabio.brandi@bayer.com, dwinterheck@gmail.com, th.paraiba1@gmail.com (2)Embrapa Meio Ambiente, Rodovia SP-340, Km 127.5, Tanquinho Velho, Caixa Postal 69, CEP 13820-000 Jaguariúna, SP, Brazil. E-mail: wagner.bettiol@embrapa.br

\begin{abstract}
The objective of this work was to evaluate the commercial formulations of Bacillus subtilis QST-713 and Bacillus pumilus QST-2808 on mycelial growth inhibition of Thielaviopsis paradoxa, for the control of the pineapple disease and growth promotion in sugarcane. The inhibition of mycelial growth was evaluated in paired culture tests. Bacillus isolates were transferred to Petri dishes 48 hours before the pathogen, and the zone of inhibition was determined. The direct effect of the autoclaved commercial formulations at $0,0.001,0.01,0.1,1.0$, and $10.0 \%$ on the inhibition of pathogen mycelial growth was evaluated. Bacillus spp. potential in controlling the disease and promoting plant growth was evaluated in assays on plant development and disease severity, both under controlled conditions and in the field. Bacillus isolates inhibited pathogen mycelial growth; however, the isolates did not control the disease effectively in the growth chamber and in the field. In the field assay without infestation by the pathogen, all treatments with biocontrol agents and fungicide increased the yield of cane stalks and sugar per hectare, compared with the control. In the assay with infestation by the pathogen, the B. pumilus-based product $\left(2.0 \mathrm{~L} \mathrm{ha}^{-1}\right)$ and fungicide differed from the control only for the variable number of tillers.
\end{abstract}

Index terms: Saccharum, Thielaviopsis paradoxa, alternative control, biological control.

\section{Formulações comerciais de Bacillus spp. para o controle da podridão-abacaxi e a promoção de crescimento em cana-de-açúcar}

Resumo - O objetivo deste trabalho foi avaliar formulações comerciais de Bacillus subtilis QST-713 e Bacillus pumilus QST-2808 na inibição do crescimento micelial de Thielaviopsis paradoxa, para o controle da podridão-abacaxi e a promoção de crescimento em cana-de-açúcar. A inibição do crescimento micelial foi avaliada em cultura pareada. Os isolados de Bacillus foram transferidos para placas de Petri 48 horas antes do patógeno, e o halo de inibição foi determinado. $\mathrm{O}$ efeito direto das formulações comerciais autoclavadas a 0 , $0,001,0,01,0,1,1,0$ e $10,0 \%$ foi avaliado quanto à inibição do crescimento micelial do patógeno. O potencial de Bacillus spp. em controlar a doença e promover o crescimento das plantas foi avaliado em ensaios quanto ao desenvolvimento das plantas e à severidade da doença, em condições controladas e em campo. Os isolados de Bacillus inibiram o crescimento micelial do patógeno; no entanto, não apresentaram controle efetivo da doença em câmara de crescimento e em campo. No ensaio de campo, sem infestação do patógeno, todos os tratamentos com agentes de biocontrole e fungicida aumentaram a produção de colmos e açúcar por hectare, em comparação à testemunha. No ensaio com infestação pelo patógeno, o produto à base de B. pumilus $(2.0 \mathrm{~L}$ $\mathrm{ha}^{-1}$ ) e o fungicida diferiram da testemunha somente quanto à variável número de perfilhos.

Termos para indexação: Saccharum, Thielaviopsis paradoxa, controle alternativo, controle biológico.

\section{Introduction}

Sugarcane is one of the most important agricultural crops in Brazil, and it is used for the production of food and biofuel (Aguiar et al., 2014). In the central region of the South of Brazil, two planting systems are used as follows: the first one lasts one and a half year, it is performed between January and March, and is more favorable for plant development; and the second one lasts one year, and it is performed between the months of October and November. However, winter planting between May and September is growing in popularity, 
with the management adapted to the driest and coldest seasons (Aguiar et al., 2014), and planting in this period can be affected by Thielaviopsis paradoxa (Ceratocystis paradoxa), a fungus that causes the pineapple disease of sugarcane. This disease is associated with retards of the bud germination and shoot development, early shoot vigor, and seed piece decay (Raid \& Rott, 2012; Chapola et al., 2014). In the state of São Paulo, Brazil, C. paradoxa is the diseasecausing agent most commonly associated with a poor germination of seed piece (Carvalho, 1963; Rossetto et al., 1986). Buds that take more than 16 days to sprout are attacked most by the pathogen (Boyd \& Galli, 1966). Even if the seed pieces are affected to a lesser extent, without the need for replanting, losses will occur in all plot cuts. These problems are aggravated by the mechanized planting, in which smaller seed pieces are used, resulting in fewer buds and more injuries (Raid \& Rott, 2012; Serafim et al., 2013; Chapola et al., 2014).

This pathogen is controlled using benzimidazoleand phenylpyridylamine-based fungicides sprayed directly on the seed pieces in the planting groove (Tokeshi \& Rago, 2005). However, synthetic products can be replaced by biocontrol agents (Banik et al., 2016; Raza et al., 2016). Bacillus spp. isolates can be used to promote vigor, growth, and the induction of resistance mechanisms in plants, in complement to the action of their metabolites (Roh et al., 2007; Francis et al., 2010). Bacillus subtilis is the most studied species (Bettiol et al., 1992; Cawoy et al., 2011; Dorighello et al., 2015; Ongena \& Jacques, 2008) with 4 to $5 \%$ of its genome specialized for the synthesis of antibiotics. This species has also the potential to produce more than 24 structurally diverse compounds during its multiplication process, including cyclic lipopeptides, such as surfactins, iturins and fengycins (Stein, 2005). George et al. (2011) reported the Bacillus spp. efficacy in vitro, in the control of $T$. paradoxa. However, there are few studies on the feasibility of T. paradoxa biocontrol by Bacillus spp. in sugarcane.

The objective of this work was to evaluate the commercial formulations of Bacillus subtilis QST-713 and Bacillus pumilus QST-2808 on mycelial growth inhibition of Thielaviopsis paradoxa, for the control of pineapple disease of sugarcane and growth promotion in sugarcane.

\section{Materials and methods}

The experiments were performedusing biofungicides based on Bacillus subtilis QST-713 [Serenade, 13.68 $\mathrm{g} \mathrm{L}^{-1}$ active ingredient (a.i.)], and Bacillus pumilus QST-2808 (Sonata, $14.35 \mathrm{~g} \mathrm{~L}^{-1}$ a.i.) obtained from Bayer CropScience. The isolate of Thielaviopsis paradoxa was provided by Dr. Modesto Barreto, from the Universidade do Estado de São Paulo, Faculdade de Ciências Agrárias e Veterinárias, and deposited under the code CMAA 1194 in the culture collection of Embrapa Meio Ambiente. The pathogen was multiplied in Petri dishes containing $20 \mathrm{~g} \mathrm{~L}^{-1}$ potato dextrose agar (PDA, Himedia), and maintained at $25 \pm 2^{\circ} \mathrm{C}$ in the dark for eight days. In order to obtain the spore suspension, $5 \mathrm{~mL}$ of autoclaved water was transferred to each plate, and the surface was scraped with a Drigalski spatula. The suspension was homogenized, and a concentration of $10^{6}$ conidia $\mathrm{mL}^{-1}$ was calibrated using a hemocytometer.

The inhibition of pathogen mycelial growth by Bacillus spp. isolates - obtained from the commercial product formulations - was evaluated in paired culture tests. For this purpose, aliquots $(100 \mu \mathrm{L})$ of each formulation were deposited on Petri dishes containing PDA medium and spread with the aid of a Drigalski spreader to obtain pure colonies of the antagonists. After 3 days of incubation at $25 \pm 2{ }^{\circ} \mathrm{C}$ in the dark, discs of B. subtilis QST-713 and B. pumilus QST2808, measuring $0.5 \mathrm{~cm}$ diameter, were transferred to one end of the Petri dishes containing PDA. After 2 days of incubation at $25 \pm 2^{\circ} \mathrm{C}$ in the dark, a PDA disk (0.5 $\mathrm{cm}$ diameter) containing the pathogen structures was transferred to the other end of the plate $(7 \mathrm{~cm}$ away from the antagonist disc). The zone of inhibition was evaluated after 4 and 9 days of incubation at $25 \pm 2^{\circ} \mathrm{C}$ in the dark.

To evaluate the effects of the heat-tolerant compounds of the formulated products on the inhibition of $T$. paradoxa mycelial growth, the compounds were added at $0,0.001,0.01,0.1,1.0$ and $10.0 \%(\mathrm{v} / \mathrm{v})$ to the PDA medium. Media formulations were autoclaved at $120^{\circ} \mathrm{C}$ for $20 \mathrm{~min}$ and poured into Petri dishes. PDA discs of $0.5 \mathrm{~cm}$ diameter containing structures of T. paradoxa were transferred to the center of the plates, and were maintained at $25 \pm 2{ }^{\circ} \mathrm{C}$ and in the dark. Evaluations were performed for four days by measuring the fungus colony diameter in both directions. 
The effects of the formulated products based on B. subtilis QST-713 and B. pumilus QST2808 on the control of the pineapple disease of sugarcane and sugarcane growth were investigated in a growth chamber. A substrate obtained from the mixture of dystrofic Oxisol (clay texture), sand, and organic matter (Multiplant 1051, Terra do Paraíso, Holambra, SP, Brazil), with $60 \%$ pine bark, $35 \%$ silt, and $5 \%$ fine sand), at 2:1:1 (v:v:v) was placed in plastic boxes $(14.5 \times 34 \times 42.5 \mathrm{~cm})$. This substrate was previously infected with a suspension of $T$. paradoxa spores up to the final concentration of $10^{4}$ spores $\mathrm{g}^{-1}$ of substrate. After 24 hours of infestation, six seed pieces of the cultivar CT-1906 containing two buds each were transplanted to each box. A treatment without infestation was maintained as an absolute control. Commercial products based on B. subtilis QST-713 and B. pumilus QST2808 at 0, 2.0, 4.0, and 8.0 $\mathrm{L} \mathrm{ha}^{-1}$ of the commercial formulation were applied to the seed pieces. The effects of a mixture of the two Bacillusbased products at $2.0 \mathrm{~L} \mathrm{ha}^{-1}$ each were also investigated. A fungicide [a.i. azoxystrobin + cyproconazole $(200+$ $\left.80 \mathrm{~g} \mathrm{~L}^{-1}\right)$ ] was used as standard treatment. In addition to these treatments, Bacillus spp.-based products at a concentration of $2.0 \mathrm{~L} \mathrm{ha}^{-1}$ were mixed separately with the commercial fungicide. The products and mixtures were applied with a $\mathrm{CO}_{2}$-pressurized backpack sprayer, simulating a commercial application in the planting furrows at volume of $200 \mathrm{~L} \mathrm{ha}^{-1}$. After the products were sprayed, the seed pieces were covered with 3 to $5 \mathrm{~cm}$ of the same substrate, and the boxes were maintained in the growth chamber between 22 and $25^{\circ} \mathrm{C}$. Irrigations were performed periodically.

The number of tillers was evaluated weekly, and the sprouting speed index (SSI) was calculated using the following formula adapted by Chapola (2010): $\mathrm{SSI}=(\mathrm{B} 1 / \mathrm{N} 1)+(\mathrm{B} 2 / \mathrm{N} 2)+\ldots+(\mathrm{Bn} / \mathrm{Nn})$, in which: $\mathrm{B} 1$, $\mathrm{B} 2, \ldots, \mathrm{Bn}$ represent the numbers of plants emerged in the respective evaluations; and N1, N2, ..., Nn represent the numbers of days after planting. At the end of the experiment, plant height and the fresh and dry weights of the shoot and root systems were evaluated. The disease severity was evaluated by longitudinally cutting the seed pieces, and measuring their length, as well as the length of the internal rot. With these data, the percentage of the seed piece tissue attacked by the pathogen was calculated. The presence of the pathogen in the seed pieces was evaluated by plating the seed piece fragments of each replicate in PDA, and incubating them at $25 \pm 2^{\circ} \mathrm{C}$, followed by microscopy analysis.

The effects of the products formulated based on B. subtilis QST-713 and B. pumilus QST-2808 on the control of the pineapple disease of sugarcane, SSI, biomass, cane production per hectare $(\mathrm{TCH})$, and sugar production per hectare (TSH) were evaluated in the commercial cultivation field of the Destilaria Destivale, of the Raízen Group at Araçatuba, SP, Brazil. The soil had the following characteristics: $\mathrm{pH}$, 4.7; OM, $18 \mathrm{~g} \mathrm{~kg}^{-1}$; $\mathrm{P}, 5 \mathrm{mg} \mathrm{cm}{ }^{-3} ; \mathrm{K}, 0.8 \mathrm{mmol}_{\mathrm{c}} \mathrm{dm}^{-3}$, $\mathrm{Ca}, 11 \mathrm{mmol}_{\mathrm{c}} \mathrm{dm}^{-3}, \mathrm{Mg}, 9 \mathrm{mmol}_{\mathrm{c}} \mathrm{dm}^{-3}, \mathrm{H}+\mathrm{Al}, 29$ $\mathrm{mmol}_{\mathrm{c}} \mathrm{dm}^{-3}$; Al, $1 \mathrm{mmol}_{\mathrm{c}} \mathrm{dm}^{-3}$; sum of bases (SB), $20.8 \mathrm{mmol}_{\mathrm{c}} \mathrm{dm}^{-3}$; cation exchange capacity (CEC), $50 \mathrm{mmol}_{\mathrm{c}} \mathrm{dm}^{-3}$; and base saturation (V), 41\%. Two experiments were carried out between June 2012 and July 2013, with or without $T$. paradoxa infestation in the planting furrows. Before planting, the area was fertilized with $470 \mathrm{~kg} \mathrm{ha}^{-1} \quad \mathrm{~N}-\mathrm{P}_{2} \mathrm{O}_{5}-\mathrm{K}_{2} \mathrm{O}$ (10-25-25), and treated with thiamethoxam $250 \mathrm{WP}\left(0.7 \mathrm{~kg} \mathrm{ha}^{-1}\right)$ to control underground insect pests. The area was also treated with sulfentrazone $500 \mathrm{WP}\left(1.5 \mathrm{~L} \mathrm{ha}^{-1}\right)$, for the control of weeds, and with carbofuran $350 \mathrm{WP}(6.5 \mathrm{~L}$ $\mathrm{ha}^{-1}$ ), for the control of nematodes.

In the soil infestation test, pathogen inocula were applied with the aid of a manual backpack sprayer at $100 \mathrm{~L} \mathrm{ha}^{-1}$ flow rate before planting. Seed pieces of sugarcane 'RB-92579' were planted at a spacing of $1.50 \mathrm{~m}$ between rows, with a mechanized planter adapted to not cover the furrows. Each plot was $4.5 \mathrm{~m}$ wide (four planting rows) by $15 \mathrm{~m}$ length, totaling $67.5 \mathrm{~m}^{2}$ of area. The seedlings were $40 \mathrm{~cm}$ long, with three to four buds each, and they were harvested mechanically in a nursery area. The planting density was 18 to 20 buds $\mathrm{m}^{-1}$ furrow. The products based on B. subtilis QST-713 and B. pumilus QST-2808, as well as the fungicide, were applied using a $\mathrm{CO}_{2}$-pressurized backpack sprayer with two 11002 fan-type nozzles, and an application of $150 \mathrm{~L} \mathrm{ha}^{-1}$ volume. After application of these products, the planting furrows were manually covered. The test without pathogen infestation was set up as described above but without application of the pathogen inoculum.

The evaluations in the two tests consisted of counting the number of emerged tillers at 30,60, and 102 days after planting, in the two central rows of each plot. With these data, the SSI was calculated. At 30 days

Pesq. agropec. bras., Brasília, v.53, n.12, p.1311-1319, Dec. 2018 DOI: $10.1590 / \mathrm{S} 0100-204 X 2018001200003$ 
after planting, evaluations of severity were performed within the useful area of each plot, by collecting three seed pieces that were longitudinally cut and classified according to the percentage of infected tissue. The following pathogen infestation scoring was used: 0 , no injury; 1 , injuries in less than $1 / 3$ of the length of the seed piece with a reddish appearance; 2, injuries in $1 / 3$ of the length of the seed piece with a reddish appearance; 3 , injuries in $2 / 3$ of the length of the seed piece with a reddish appearance; 4 , injuries in the total length of the seed piece with a reddish appearance; and 5 , injuries in the total length of the seed piece with a blackened appearance. At 191 days after planting, the entire shoot of the plants was collected in $1 \mathrm{~m}$ furrow within the useful area of each plot, and weighed to determine shoot biomass.

All rows of each plot were harvested on 7/27/2013, with the aid of a mechanical harvester. Cane stalks were weighed in a scale coupled to the transport trailer, and data were converted into megagrams of cane per hectare (TCH). Samples of cane stalks collected from each plot were removed, placed in plastic bags, and taken to the laboratory to measure total recoverable sugar (TRS, expressed in $\mathrm{kg} \mathrm{Mg}^{-1}$ ), which corresponds to the amount of sugar available in the raw material. With these two variables, the value converted for megagrams of sugar hectare $(\mathrm{TSH}=\mathrm{TCH} \times \mathrm{TRS} / 1000)$ was calculated.

In the assay evaluating the zone of inhibition produced by Bacillus spp., a t-test was applied to analyze the significant differences between isolates. In the assays evaluating the inhibition of mycelial growth of $T$. paradoxa, a $2 \times 5$ factorial arrangement was used (B. subtilis QST-713 and B. pumilus QST2808; five concentrations), in a completely randomized experimental design, with seven replicates. The data were transformed $(\log )$ and analyzed using the twofactor Kruskal-Wallis test, at $1 \%$ probability, followed by regression analysis. The assay conducted in the grown-chamber followed a completely randomized design, with four replicates, with six sugarcane seed pieces each. The design of the field experiments was a randomized complete block design with four replicates. For the analysis of these data, the assumptions of the analysis of variance were tested, and if significant, the log transformation was applied. The analysis of variance was applied at $5 \%$ probability to the normal data that presented homoscedasticity of variances.
If significant differences between treatments were observed, the Scott-Knott multiple comparison test at $1 \%$ probability was performed. The analysis of the nonparametric data, such as severity in the field experiment, was performed using the Kruskal-Wallis test, at 5\% probability. All analyses were performed using R statistical software (R Core Team, 2017). The ExpDes package (Ferreira et al., 2014) was used for the analyses of the experiments in completely randomized design and randomized blocks, and the lsmeans package (Lenth, 2016) was used for the comparison between the regression models.

\section{Results and Discussion}

In the work using the paired culture technique, to evaluate the zone of inhibition formed by the B. subtilis QST-713 and B. pumilus QST-2808 isolates, zones of inhibition of $2.16 \mathrm{~cm}$ and $2.21 \mathrm{~cm}$, respectively, were observed for the Bacillus isolates on the fourth day. On the ninth day, the zones of inhibition measured $2.01 \mathrm{~cm}$ and $1.74 \mathrm{~cm}$ for the B. subtilis and B. pumilus isolates, respectively. On both evaluation days (4 and 9 days of incubation), no significant differences between the zones of inhibition were detected by the t-test $(p=0.68$ and $\mathrm{p}=0.14$ ).

The inhibition of the pathogen mycelial growth by B. subtilis and B. pumilus based products at different concentrations showed no significant interaction between the studied factors. However, a significant difference was observed between the products and concentrations incorporated into the culture medium. The commercial product based on B. subtilis QST713 completely inhibited the growth of $T$. paradoxa at concentrations of 1.0 and $10.0 \%$. The inhibition was $77.0,67.3$, and $0.0 \%$ for the concentrations at 0.1 , 0.01 , and $0.001 \%$, respectively, of this product (Figure 1). For the B. pumilus QST-2808 based product, the inhibition of the pathogen mycelial growth was 79.8 and $35.3 \%$ for the concentrations of 10.0 and $1.0 \%$ of the product, respectively. B. pumilus QST-2808 based product at $0.1,0.01$, and $0.001 \%$ did not inhibit the growth of $T$. paradoxa (Figure 1). The comparison between the linear models showed that there were no significant differences between the slopes of the used products. However, this comparison showed that the product based on $B$. subtilis QST-713 significantly inhibited the growth of $T$. paradoxa at 
lower concentrations than the B. pumilus QST-2808based product, with $\mathrm{ED}_{50}$ values of 0.015 and $2.39 \%$, respectively (Figure 1).

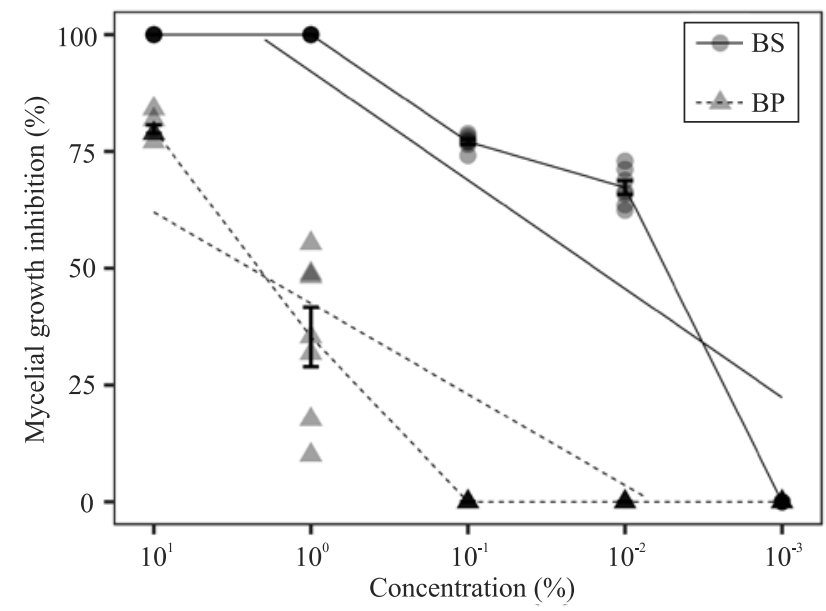

Figure 1. Inhibition of mycelial growth of Thielaviopsis paradoxa by products based on Bacillus subtilis QST-713 (BS; cp Serenade-BS) and Bacillus pumilus QST-2808 (BP; cp Sonata-BP). For BS y $=92.14+23.27 x, \mathrm{R}^{2}=0.8$; for $\mathrm{BP}$ $\mathrm{y}=42.49+19.48 \mathrm{x}, \mathrm{R}^{2}=0.73$.
According to Pérez-García et al. (2010), antibiosis is the main mechanism of action of Bacillus, and it is possible to affirm that the inhibition observed is directly on the growth of the pathogen. However, these antagonists also act by competition for space and nutrients, as well as synthesis of volatile organic compounds (Lanna Filho et al., 2010; Pérez-García et al., 2010). In addition to inhibiting the mycelial growth, $B$. subtilis isolates inhibit the spore germination, such as that of the urediniospores of Phakopsora pachyrhizi (Dorighello et al., 2015), urediniospores of Hemileia vastatrix (Bettiol \& Varzea, 1992), and spores of Pyricularia oryzae (Bettiol \& Kimati, 1990).

Some substances produced by the Bacillus isolates present in the formulations are tolerant to heat. Ongena \& Jacques (2008) and Stein (2005) found that B. subtilis produces heat-tolerant substances. For B. subtilis QST-713, which produced fengycin, iturin and surfactin, the highest concentrations of the formulation in the culture medium were those that completely inhibited the mycelial growth of the pathogen (Figure 1). Moreira et al. (2014) showed that the metabolites present in the commercial formulation of B. subtilis QST-713 inhibited the mycelial growth of

Table 1. Effect of the commercial formulations based on Bacillus subtilis QST-713 (BS), Bacillus pumilus QST-2808 (BP), fungicide (F), and of the mixtures of these products on the plant development and on the severity of "pineapple disease" (Thielaviopsis paradoxa) of sugarcane on sugarcane cultivar CT1906 in a growth chamber ${ }^{(1)}$.

\begin{tabular}{|c|c|c|c|c|c|c|c|c|}
\hline \multirow[t]{2}{*}{ Treatment $^{(2)}$} & \multirow[t]{2}{*}{$\mathrm{NT}^{\mathrm{ns}}$} & \multirow{2}{*}{$\begin{array}{l}\text { Height } \\
(\mathrm{cm})\end{array}$} & \multirow[t]{2}{*}{ SSI } & \multicolumn{2}{|c|}{ Fresh weight } & \multicolumn{2}{|c|}{ Dry weight } & \multirow[t]{2}{*}{ Severity ${ }^{\text {ns }}$} \\
\hline & & & & Shoot & Root $^{\text {ns }}$ & Shoot $^{\mathrm{ns}}$ & Root $^{\text {ns }}$ & \\
\hline $\mathrm{BP}\left(2.0 \mathrm{~L} \mathrm{ha}^{-1}\right)$ & 7.7 & $71.9 \mathrm{~b}$ & 1.09 & $9.33 b$ & 11.74 & 1.28 & 1.55 & 88.8 \\
\hline $\mathrm{BP}\left(4.0 \mathrm{~L} \mathrm{ha}^{-1}\right)$ & 6.0 & $70.3 b$ & 0.72 & $9.35 b$ & 12.55 & 1.28 & 1.66 & 87.2 \\
\hline $\mathrm{BP}\left(8.0 \mathrm{~L} \mathrm{ha}^{-1}\right)$ & 5.5 & $68.6 b$ & 0.70 & $10.55 b$ & 14.41 & 1.35 & 2.07 & 91.6 \\
\hline BS $\left(2.0 \mathrm{~L} \mathrm{ha}^{-1}\right)$ & 5.7 & $70.9 b$ & 0.74 & $9.48 \mathrm{~b}$ & 10.24 & 1.29 & 1.33 & 94.8 \\
\hline BS $\left(4.0 \mathrm{~L} \mathrm{ha}^{-1}\right)$ & 4.2 & $71.7 \mathrm{~b}$ & 0.59 & $8.50 \mathrm{~b}$ & 17.76 & 1.17 & 2.01 & 84.4 \\
\hline $\mathrm{BS}\left(8.0 \mathrm{~L} \mathrm{ha}^{-1}\right)$ & 5.2 & $56.1 \mathrm{~b}$ & 0.53 & $6.58 \mathrm{~b}$ & 11.10 & 0.86 & 1.18 & 86.3 \\
\hline $\mathrm{BP}+\mathrm{BS}\left(2\right.$ and $\left.2 \mathrm{~L} \mathrm{ha}^{-1}\right)$ & 4.7 & $81.1 \mathrm{a}$ & 0.63 & $12.07 \mathrm{a}$ & 17.12 & 1.52 & 1.99 & 85.3 \\
\hline $\mathrm{BP}+\mathrm{F}\left(2.0 \mathrm{~L} \mathrm{ha}^{-1}\right.$ and $\left.0.25 \mathrm{~mL} \mathrm{~L}^{-1}\right)$ & 6.0 & $68.6 \mathrm{~b}$ & 0.79 & $13.27 \mathrm{a}$ & 11.83 & 1.48 & 1.34 & 88.3 \\
\hline $\mathrm{BS}+\mathrm{F}\left(2.0 \mathrm{~L} \mathrm{ha}^{-1}\right.$ and $\left.0.25 \mathrm{~mL} \mathrm{~L}^{-1}\right)$ & 6.0 & $82.9 \mathrm{a}$ & 0.93 & $12.46 \mathrm{a}$ & 16.59 & 1.71 & 1.93 & 85.5 \\
\hline $\mathrm{F}\left(0.25 \mathrm{~mL} \mathrm{~L}^{-1}\right)$ & 4.7 & $60.7 \mathrm{~b}$ & 0.57 & $8.05 b$ & 17.49 & 1.22 & 1.95 & 97.0 \\
\hline Inoculated control & 5.0 & $72.8 b$ & 0.58 & $10.39 \mathrm{~b}$ & 15.77 & 1.26 & 1.73 & 100.0 \\
\hline Absolute control & 6.7 & $97.3 \mathrm{a}$ & 1.00 & $16.24 \mathrm{a}$ & 16.17 & 2.11 & 2.93 & 75.12 \\
\hline Coefficient of variation (\%) & 31.8 & 19.3 & - & 33.1 & 45.3 & 36.9 & 36.6 & 12.1 \\
\hline
\end{tabular}

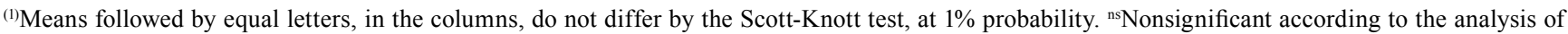
variance at $5 \%$ probability. ${ }^{(2)} \mathrm{BS}$, Bacillus subtilis-based formulation (commercial product Serenade); BP, Bacillus pumilus-based formulation (commercial product Sonata); F, a.i. azoxystrobin + cyproconazole. NT, number of tillers; SSI, sprouting speed index. 
Colletotrichum acutatum, and that the volatile organic compounds produced by this isolate are efficient in controlling the pathogen.

In the experiment evaluating the effects of Bacillus spp. for the control of pineapple disease of sugarcane, and on the growth of plants cultivated in the growthchamber, no significant differences were observed among the products, applied doses, or product mixtures, in comparison to the controls, for the number of tillers, root fresh weight, shoot and root dry weights, and disease severity (Table 1). However, although no significant differences were observed in the plants of the absolute control treatment, whose seed pieces were neither treated nor inoculated with the pathogen, they had higher values for plant height, shoot fresh weight, and shoot and root dry weights, indicating the losses that this pathogen can cause to the crop (Table 1). Only the variables of height and shoot fresh weight showed significant differences among treatments. The product mixtures $(\mathrm{BP}+\mathrm{BS}$ and $\mathrm{BS}+\mathrm{F})$ and the absolute control showed the greatest height values. These same treatments, in addition to $\mathrm{BP}+\mathrm{F}$, also had the greatest shoot fresh weight values (Table 1).

In the test evaluating the effect of the application of Bacillus spp. on the control of pineapple disease of sugarcane, in an artificially infested soil in the field, the number of tillers and TSH showed significant differences among the treatments (Table 2). The application of fungicide and B. pumilus QST-2808 (2.0 $\left.\mathrm{L} \mathrm{ha}^{-1}\right)$ were the treatments that showed the highest number of tillers, differing significantly from the other treatments. Biomass, disease severity, and $\mathrm{TCH}$ showed no significant differences among treatments. Bacillus pumilus QST-2808 (2.0 $\left.\mathrm{L} \mathrm{ha}^{-1}\right)$ and the BP $+\mathrm{F}$ mixture reduced the amount of TSH in comparison to the other treatments (Table 2). Although no statistical test was applied to the SSI data, it showed that all treatments were superior to the control with emphasis on the treatments with fungicide and B. pumilus 2.0 $\mathrm{L} \mathrm{ha}{ }^{-1}$, which showed an increase of up to $28 \%$ in SSI (Figure 2). However, none of the treatments had an effect on the control of the disease in the present studied conditions. This finding may explain the lack of registration of these biological products for the control of pineapple disease of sugarcane.

The field experiment without soil infestation with $T$. paradoxa was used to evaluate the effect of the products on plant development. In this assay, no differences were observed between the number of tillers, biomass, and disease severity among treatments (Table 2). The only variables that showed significant differences among treatments were $\mathrm{TCH}$ and $\mathrm{TSH}$. TCH was significantly lower in the control and BS $+\mathrm{F}$ treatments, and all other treatments showed higher values than the control. The

Table 2. Effect of the commercial formulations based on Bacillus subtilis QST-713 (BS), Bacillus pumilus QST-2808 (BP), fungicide (F) and of the mixtures of these product on the number of tillers (NT), shoot biomass (Bio), tons of cane per hectare $(\mathrm{TCH})$, tons of sugar per hectare (TSH), and severity (Sev) of pineapple disease of sugarcane (Thielaviopsis paradoxa) in sugarcane variety RB-92579 cultivated on soils infested and not infested with the pathogen ${ }^{(1)}$.

\begin{tabular}{|c|c|c|c|c|c|c|c|c|c|c|}
\hline \multirow[t]{2}{*}{ Treatment $^{(2)}$} & \multicolumn{5}{|c|}{ Infested } & \multicolumn{5}{|c|}{ Noninfested } \\
\hline & NT & $\mathrm{Bio}^{\mathrm{ns}}$ & $\mathrm{Sev}^{\mathrm{ns}}$ & $\begin{array}{c}\text { TCH } \\
\left(\text { Mg cane ha }^{-1}\right)\end{array}$ & $\begin{array}{c}\text { TSH } \\
\left(\mathrm{Mg} \mathrm{sugar} \mathrm{ha-1}^{-1}\right)\end{array}$ & NT & $\mathrm{Bio}^{\mathrm{ns}}$ & $\mathrm{Sev}^{\mathrm{ns}}$ & $\begin{array}{c}\text { TCH } \\
\left(\mathrm{Mg} \text { cane ha }^{-1}\right)\end{array}$ & $\begin{array}{c}\text { TSH } \\
\left(\mathrm{Mg} \mathrm{sugar} \mathrm{ha-1}^{-1}\right)\end{array}$ \\
\hline $\mathrm{BP}\left(2.0 \mathrm{~L} \mathrm{ha}^{-1}\right.$ & $282.5 \mathrm{a}$ & 16.52 & 3.41 & 150.42 & $19.10 \mathrm{~b}$ & 221.3 & 18.15 & 3.92 & $156.2 \mathrm{a}$ & $20.94 b$ \\
\hline $\mathrm{BP}\left(4.0 \mathrm{~L} \mathrm{ha}^{-1}\right)$ & $220.7 b$ & 14.52 & 3.66 & 158.90 & $20.35 \mathrm{a}$ & 243.7 & 14.65 & 3.33 & $144.3 b$ & $17.99 b$ \\
\hline $\mathrm{BP}\left(8.0 \mathrm{~L} \mathrm{ha}^{-1}\right)$ & $201.3 b$ & 12.85 & 3.90 & 152.85 & $20.07 \mathrm{a}$ & 285.5 & 20.17 & 3.00 & $145.0 \mathrm{~b}$ & $20.06 \mathrm{~b}$ \\
\hline BS $\left(2.0 \mathrm{~L} \mathrm{ha}^{-1}\right)$ & $229.0 \mathrm{~b}$ & 18.22 & 3.67 & 148.31 & $20.02 \mathrm{a}$ & 187.0 & 16,40 & 3.85 & $141.0 \mathrm{~b}$ & $19.65 b$ \\
\hline BS $\left(4.0 \mathrm{~L} \mathrm{ha}^{-1}\right)$ & $227.3 b$ & 14.47 & 3.93 & 153.15 & $20.03 \mathrm{a}$ & 256.5 & 21.03 & 4.10 & $131.1 \mathrm{~b}$ & $18.12 b$ \\
\hline $\mathrm{BS}\left(8.0 \mathrm{~L} \mathrm{ha}^{-1}\right)$ & $205.7 b$ & 16,40 & 3.67 & 153.15 & $19.55 \mathrm{a}$ & 278.0 & 14.46 & 3.58 & $131.9 \mathrm{~b}$ & $18.95 b$ \\
\hline $\mathrm{BP}+\mathrm{F}\left(2.0 \mathrm{~L} \mathrm{ha}^{-1}+0.25 \mathrm{~mL} \mathrm{~L}^{-1}\right)$ & $193.5 b$ & 17.42 & 3.32 & 149.21 & $19.36 \mathrm{~b}$ & 245.3 & 21.61 & 3.67 & $150.1 \mathrm{a}$ & $19.46 \mathrm{~b}$ \\
\hline $\mathrm{BS}+\mathrm{F}\left(2.0 \mathrm{~L} \mathrm{ha}^{-1}+0.25 \mathrm{~mL} \mathrm{~L}^{-1}\right)$ & $205.7 b$ & 13.42 & 4.08 & 151.03 & $19.65 \mathrm{a}$ & 310.5 & 19.35 & 3.33 & $128.0 \mathrm{c}$ & $17.79 b$ \\
\hline $\mathrm{F}\left(0.25 \mathrm{~mL} \mathrm{~L}^{-1}\right)$ & $290.0 \mathrm{a}$ & 23.55 & 3.91 & 148.91 & $20.32 \mathrm{a}$ & 267.0 & 17.62 & 3.50 & $147.7 \mathrm{a}$ & $21.07 \mathrm{a}$ \\
\hline Control & $197.0 \mathrm{~b}$ & 14.77 & 3.91 & 154.06 & $20.82 \mathrm{a}$ & 248.0 & 22.44 & 3.25 & $128.0 \mathrm{c}$ & $17.67 \mathrm{c}$ \\
\hline Coefficient of variation (\%) & 16.9 & 30.8 & 7.3 & 9.1 & 9.7 & 19.9 & 27.5 & 14.7 & 11.3 & 13.7 \\
\hline
\end{tabular}

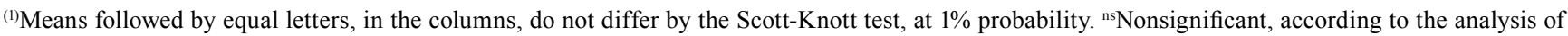
variance, at $5 \%$ probability, or by the Kruskal-Wallis test, at $5 \%$ probability. ${ }^{(2)} \mathrm{BS}$, Bacillus subtilis-based formulation (commercial product Serenade); BP, Bacillus pumilus-based formulation (commercial product Sonata); F, a.i. azoxystrobin + cyproconazole. NT, number of tillers; Bio, shoot biomass (kg per linear meter of furrow). 
highest values were observed for BP $\left(2.0 \mathrm{~L} \mathrm{ha}^{-1}\right)$, BP $+\mathrm{F}$, and fungicide only, which differed significantly from the others. For TSH, all the treatments were significantly higher than the control, and the highest value was observed for the treatment with the fungicide application, which differed from the others (Table 2). As mentioned previously, no statistical test was applied to the SSI data from the field experiment. However, SSI increased with increasing concentrations of Bacillus spp. (Figure 2).

The SSI is an important parameter for the study of pineapple disease of sugarcane because higher SSI values indicate a greater chance of escape from the pathogen attack. As soon as plants emerge and start photosynthesis, buds become resistant to fungal attack, and seedling destruction is almost completely stopped (Tokeshi, 1980). In the field experiments without soil infestation by the pathogen, the SSI increased with increasing doses of the commercial products formulated with B. subtilis QST-713 and B. pumilus QST-2808. However, no effects were observed on the other evaluated variables. These results may be due to the characteristics of the studied products. Sundara et al. (2002) evaluated a Bacillus megaterium var. phosphaticum isolate applied to the planting furrow and cane ratoon, and found significant increases in tillering and seed piece weight, leading to a yield increase of $12.6 \%$. This positive effect is due to the greater availability of phosphorus to the plant due to the specific action of this isolate in transforming insoluble phosphorus from the soil into soluble phosphorus readily assimilable by the plant, and not due to a probable effect on the pathogen control (Sundara et al., 2002).

Angulo et al. (2014) identified isolates of Bacillus spp. from roots of eucalyptus plants with the capacity to produce indoleacetic acid and solubilize phosphate for seedlings, increasing plant growth and vigor. Therefore, for Bacillus spp., the potential action as a plant growth-promoting rhizobacteria should also be considered, taking into account its interaction with the plant/pathogen/environment system (Schippers, 1992). A product containing a mixture of $B$. subtilis $\mathrm{CH} 200$ and Bacillus licheniformis $\mathrm{CH} 201$ is registered in the Brazilian market as a promoter of growth, and increased cotton shoot weight when compared to the control plants with or without inoculation of Meloidogyne incognita (Montalvão, 2016). The same isolates in a mixture are registered for the control of several nematodes in lettuce, rice, soybean, and sugarcane

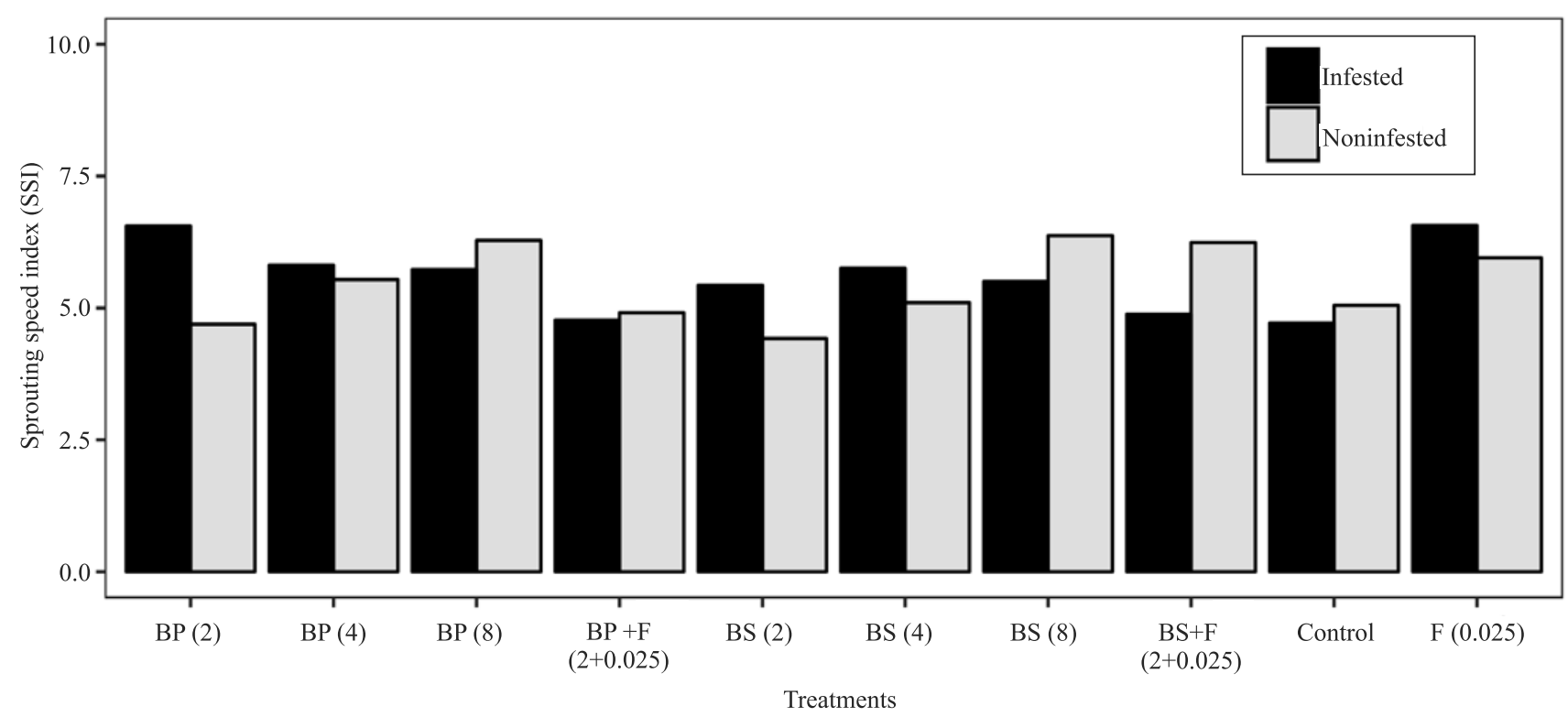

Figure 2. Effect of products based on Bacillus pumilus QST-2808 (BP), Bacillus subtilis QST-713 (BS) and fungicide (a.i. azoxystrobin + cyproconazole) on the sprouting speed index of sugarcane cultivated in infested and noninfested field with Thielaviopsis paradoxa. The concentration of the applied product is identified in parentheses in $\mathrm{L} \mathrm{ha}{ }^{-1}$. 
(Agrofit, 2015). Santos \& Rigobelo (2016) found that the product containing a mixture of $B$. subtilis $\mathrm{CH} 200$ and $B$. licheniformis $\mathrm{CH} 201$ significantly increases the root system dry weight of presprouted sugarcane seedlings, but they did not observe a significant effect for shoot dry matter. Silva et al. (2015) found that Bacillus spp. promotes growth in sugarcane seedlings. However, in the present study, no positive effects were observed on plant development from the commercial products based on B. subtilis QST-713, or B. pumilus QST-2808, as well as mixtures of these isolates. These results indicate that there is a need to properly select Bacillus isolates with potential to promote plant growth and to control plant pathogens. In addition, it is essential to investigate the application method of Bacillus spp.

\section{Conclusions}

1. Bacillus subtilis QST-713 and Bacillus pumilus QST-2808 inhibit the mycelial growth of Thielaviopsis paradoxa in vitro, as measured by the zone of inhibition test and the incorporation into culture medium of the heat-tolerant compounds present in the commercial products.

2. The commercial products based on Bacillus subtilis QST-713 and Bacillus pumilus QST-2808 do not control the pineapple disease of sugarcane, and they do not promote sugarcane growth in the growth chamber, or in the field.

\section{Acknowledgments}

To Coordenação de Aperfeiçoamento de Pessoal de Nível Superior (Capes), for the scholarship granted; and to Conselho Nacional de Desenvolvimento Científico e Tecnológico (CNPq), for the scholarship and productivity fellowship granted (process number 305818/2015-5).

\section{References}

AGROFIT: Sistema de Agrotóxicos Fitossanitários. Available at: $<$ http://agrofit.agricultura.gov.br/agrofit_cons/principal_agrofit_ cons>. Accessed on: Feb. 182015.

AGUIAR, A.T. da E.; GONÇALVES, C.; PATERNIANI, M.E.A.G.Z.; TUCCI, M.L.S.; CASTRO, C.E.F. de (Ed.). Instruções agrícolas para as principais culturas econômicas. 7.ed. rev. e atual. Campinas: IAC, 2014. 452p. (IAC. Boletim, 200).

ANGULO, C.V.; SANFUENTES, E.A.; RODRÍGUEZ, F.; SOSSA, K.E. Caracterización de rhizobacterias promotoras de crecimiento en plántulas de Eucalyptus nitens. Revista Argentina de Microbiología, v.46, p.338-347, 2014. DOI: 10.1016/S03257541(14)70093-8.

BANIK, A.; MUKHOPADHAYA, S.K.; DANGAR. T.K. Characterization of N2-fixing plant growth promoting endophytic and epiphytic bacterial community of Indian cultivated and wild rice (Oryza spp.) genotypes. Planta, v.243, p.799-812, 2016. DOI: 10.1007/s00425-015-2444-8.

BETTIOL, W.; BRANDÃO, M.S.B.; SAITO, M.L. Controle da ferrugem do feijoeiro com extratos e células formuladas de Bacillus subtilis. Summa Phytopathologica, v.18, p.153-159, 1992.

BETTIOL, W.; KIMATI, H. Efeito de Bacillus subtilis sobre Pyricularia oryzae agente causal da brusone do arroz. Pesquisa Agropecuária Brasileira, v.25, p.1165-1174, 1990.

BETTIOL, W.; VARZEA, V.M.P. Controle biológico da ferrugem (Hemileia vastatrix) do cafeeiro com Bacillus subtilis em condições controladas. Fitopatologia Brasileira, v.17, p.91-95, 1992.

BOYD, H.; GALLI, F. Efeito do armazenamento de cana-deaçúcar sôbre a "germinação" e sôbre a incidência da podridãoabacaxi, causada por Ceratocystis paradoxa (de Seynes) Moreau. Anais da Escola Superior de Agricultura "Luiz de Queiroz", v.23, p. 229-245, 1966. DOI: 10.1590/S0071-12761966000100021.

CARVALHO, P.C.T. Estudos das podridões dos toletes de canade-açúcar. 1963. 98p. Tese (Doutorado) - Universidade de São Paulo, Piracicaba.

CAWOY, H.; BETTIOL, W.; FICKERS, P.; ONGENA, M. Bacillus-based biological control of plant diseases. In: STOYTCHEVA, M. (Ed). Pesticides in the modern world pesticides use and management. Rijeka: InTech, 2011. p.273-302 DOI: $10.5772 / 17184$.

CHAPOLA, R.G.; OGASAWARA, G.A.; JANS, B.; MASSOLA JUNIOR, N.S. Controle da podridão abacaxi da cana-de-açúcar por meio da pulverização de fungicidas em rebolos no sulco de plantio. Ciência Rural, v.44, p.197-202, 2014. DOI: 10.1590/ S0103-84782014000200001.

CHAPOLA, R.G. Controle da podridão abacaxi da cana-deaçúcar por meio da pulverização de fungicidas em mudas no sulco de plantio. 2010. 77p. Dissertação (Mestrado) Universidade de São Paulo, Piracicaba. DOI: 10.11606/D.11.2011. tde-11022011-153008.

DORIGHELlO, D.V.; BETTIOL, W.; MAIA, N.B.; LEITE, R.M.V.B. de C. Controlling Asian soybean rust (Phakopsora pachyrhizi) with Bacillus spp. and coffee oil. Crop Protection, v.67, p.59-65, 2015. DOI: 10.1016/j.cropro.2014.09.017.

FERREIRA, E.B.; CAVALCANTI, P.P.; NOGUEIRA, D.A. ExpDes: an R package for ANOVA and experimental designs. Applied Mathematics, v.5, p.2952-2958, 2014. DOI: 10.4236/ am.2014.519280.

FRANCIS, I.; HOLSTERS, M.; VEREECKE, D. The Grampositive side of plant-microbe interactions. Environmental Microbiology, v.12, p.1-12, 2010. DOI: 10.1111/j.14622920.2009.01989.x. 
GEORGE, P.; GUPTA, A.; GOPAL, M.; CHANDRAMOHANAN, R.; THOMAS, L.; THOMAS, G.V. Antagonistic activity of coconut rhizospheric and endophytic Bacillus spp. against Ganoderma applanatum and Thielaviopsis paradoxa. Journal of Plantation Crops, v.39, p.278-284, 2011.

LANNA FILHO, R.; FERRO, H.M.; PINHO, R.S.C. de. Controle biológico mediado por Bacillus subtilis. Revista Trópica Ciências Agrárias e Biológicas. v.4, p.12-20, 2010.

LENTH, R.V. Least-Squares Means: The R Package lsmeans. Journal of Statistical Software, v.69, p.1-33, 2016. DOI: 10.18637/ jss.v069.i01.

MONTALVÃO, S.C.L. Uso de Bacillus spp. para o controle de Fusarium oxysporum f. sp. vasinfectum e Meloidogyne incognita no algodoeiro (Gossypium hirsutum). 2016. 170p. Tese (Doutorado) - Universidade de Brasília, Brasília.

MOREIRA, R.R.; NESI, C.N.; MAY DE MIO, L.L. Bacillus spp. and Pseudomonas putida as inhibitors of the Colletotrichum acutatum group and potential to control Glomerella leaf spot. Biological Control, v.72. p.30-37, 2014. DOI: 10.1016/j. biocontrol.2014.02.001.

ONGENA, M.; JACQUES, P. Bacillus lipopeptides: versatile weapons for plant disease biocontrol. Trends in Microbiology, v.16, p.115-125, 2008. DOI: 10.1016/j.tim.2007.12.009.

PÉREZ-GARCÍA, A.; ROMERO, D.; VICENTE, A. de. Plant protection and growth stimulation by microorganisms: biotechnological applications of Bacilli in agriculture. Current Opinion in Biotechnology, v.22, p.187-193, 2010. DOI: 10.1016/j. copbio.2010.12.003.

R CORE TEAM. R: A language and environment for statistical computing. Vienna: R Foundation for Statistical Computing, 2017.

RAID, R.N.; ROTT, P. Sugarcane pineapple disease of sugarcane or Sugarcane Pineapple Set Rot. In: RICE, W.R. (Ed.). Sugarcane Handbook. Gainesville: University of Florida, Institute of Food and Agricultural Sciences, 2012. p.1-3. SS-AGR-205.

RAZA, W.; YOUSAF, S.; RAJER, F.U. Plant growth promoting activity of volatile organic compounds produced by biocontrol strains. Science Letters, v.4, p.40-43, 2016.

ROH, J.Y.; CHOI, J.Y.; LI, M.S.; JIN, B.R.; JE, Y.H. Bacillus thuringiensis as a specific, safe, and effective tool for insect pest control. Journal of Microbiology and Biotechnology, v.17, p.547-559, 2007.
ROSSETTO, C.J.; LOURENÇÃO, A.L.; SPIRONELO, A.; IGUE, T.; RIBEIRO, I.J.A. Ocorrência do complexo Carpophilus humeralis (Fabricius) - Ceratocystis paradoxa (De Seynes) Moreau em cana-de-açúcar no Estado de São Paulo. Bragantia, v.45, p.171-178, 1986. DOI: 10.1590/S0006-87051986000100016.

SANTOS, R.M. dos; RIGOBELO, E.C. Uso de Bacillus subtilis e Bacillus licheniformis na promoção de crescimento de mudas pré-brotadas de cana-de-açúcar. Ciência \& Tecnologia: FatecJB, v.8, p.1-5, 2016. Número especial.

SCHIPPERS, B. Prospects for management of natural suppressiveness to control soilborne pathogens. In: TJAMOS, E.C.; PAPAVIZAS, G.C.; COOK, R.J. (Ed.). Biological Control of Plant Diseases: progress and challenges for the future. New York: Plenum Press, 1992, p.21-34. DOI: 10.1007/978-1-47579468-7_3.

SERAFIM, G.G.; STOLF, R.; SILVA, J.R.; SILVA, L.C.F.; MANIERO, M.A.; BASSINELLO, A.I. Influência do plantio mecanizado no índice de brotação de cana-de-açúcar. STAB, v.31, p.22-25, 2013.

SILVA, J.M. da; SANTOS, T.M.C. dos; ALBUQUERQUE, L.S. de; MONTALDO, Y.C.; OLIVEIRA, J.U.L. de; SILVA, S.G.M. da; NASCIMENTO, M.S.; TEIXEIRA, R. da R.O. Potential of endophytic bacteria (Herbaspirillum spp. and Bacillus spp.) to promote sugarcane growth. Australian Journal of Crop Science, v.9, p.754-760, 2015.

STEIN, T. Bacillus subtilis antibiotics: structures, syntheses and specific functions. Molecular Microbiology, v.56, p.845-857, 2005. DOI: 10.1111/j.1365-2958.2005.04587.x.

SUNDARA, B.; NATARAJAN, V.; HARI, K. Influence of phosphorus solubilizing bacteria on the changes in soil available phosphorus and sugarcane and sugar yields. Field Crops Research, v.77, p.43-49, 2002. DOI: 10.1016/S0378-4290(02)00048-5.

TOKESHI, H. Doenças da cana-de-açúcar. In: GALLI, F. (Coord.). Manual de fitopatologia: doenças das plantas cultivadas. São Paulo: Agronômica Ceres, 1980. v.2, p.141-206.

TOKESHI, H.; RAGO, A. M. Doenças da cana-de-açúcar. In: KIMATI, H.; AMORIM, L.; REZENDE J.A.M.; BERGAMIN FILHO, A.; CAMARGO, L.E.A. (Ed.). Manual de fitopatologia: doenças das plantas cultivadas. 4.ed. São Paulo: Agronômica Ceres, 2005. v.2, p.185-196.

Received on July 7, 2017 and accepted on September 3, 2018

Pesq. agropec. bras., Brasília, v.53, n.12, p.1311-1319, Dec. 2018 DOI: $10.1590 / \mathrm{S} 0100-204 \mathrm{X} 2018001200003$ 